\title{
AOR
}

Selected Papers of \#AolR2021:

The 22nd Annual Conference of the

Association of Internet Researchers

Virtual Event / 13-16 Oct 2021

\section{SUBVERSIVE COMMEMORATION: MAPPING THE ASSEMBLAGE OF COUNTER-MEMORY ON TWITTER}

\author{
Fatima Gaw \\ University of the Philippines \\ Jon Benedik Bunquin \\ University of the Philippines
}

\section{Technologies of (counter)memory}

When institutions fail to sanction the past and history is contested, memory becomes susceptible to political manipulation. In the Philippines, public memory of the dictator Ferdinand Marcos has been whitewashed by narratives distorting and denying his crimes, including theft of billions of public funds, torture and murder (Aguilar, 2019). While online disinformation networks rehabilitate his legacy (Soriano \& Gaw, 2021), political allies legitimize his regime by legislating 'Marcos Day' to commemorate his birth anniversary (House Bill No. 7137, 2020). In response, the Twitter hashtag network \#ArawNgMagnanakaw ('Day of Thieves') performed its counter commemoration of Marcos, gaining prominence in digital and mainstream media.

The case of \#ArawNgMagnanakaw illustrates how digital media facilitates the construction and negotiation of memory by new actors in new contexts. Beyond digital media enabling participatory forms of memory-making (Liu, 2018), we argue that technologies of memory (Armstrong \& Crage, 2006) reconfigure power relations in memory construction. Engaging the concept of counter-memory (Foucault, 1977), we examine how digital media sets the conditions to resist elite narratives by enabling nonconventional ways of remembering. We locate the performance of counter-memory work in the intersection of networked publics, counter-narratives, and technologies of memories. In investigating the hashtag network \#ArawNgMagnanakaw, we theorize the 'assemblage of counter-memory' as the connective, discursive, and material assemblage that enact political agency to privilege marginalized narratives and play an active role in the (re)construction of memory.

We employed a mixed-methods approach in studying the \#ArawNgMagnanakaw assemblage of counter-memory. Through nodeXL, we collected tweets posted from

Suggested Citation (APA): Gaw, F. \& Bunquin, J.B. (2021, October). Subversive Commemoration: Mapping the Assemblage of Counter-memory on Twitter. Paper presented at AolR 2021: The 22nd Annual Conference of the Association of Internet Researchers. Virtual Event: AolR. Retrieved from http://spir.aoir.org. 
September 2 to 13, 2020 with the hashtag \#ArawNgMagnanakaw. The hashtag network comprised 18,067 tweets from 8,896 users, which we identified into categories of public figures, organizations and users. We then generated clusters from the network and examined their sizes and the central actors per cluster. We visualized the structure of the network using the Gephi. We also analyzed Tweet discourses from the unique tweets per cluster through the lens of digital practices (Jones, Chik \& Hafner, 2015), where we examined texts, images, links and interactions as discursive practices and paid attention to their re/appropriation of Twitter affordances (reply, retweet, quote tweet, hashtag).

\section{Networked subversion and unconventional commemoration}

We find that the counter-memory assemblage derives its power by resisting traditional, institutional, and mainstream structures, discourses, and practices of remembrance. The counter-memory network on Twitter is decentralized yet connected by the hashtag, drawing credibility from traditional historical agents (e.g. scholars and media) but enacting legitimacy through multiple, disparate but corroborative users (Figure 1). Our analysis shows the formation of communities clustering around unconventional sources of historical information, such as microcelebrities and non-affiliated users. As a technology of memory, Twitter capacitates sources considered 'unqualified' in traditional media to challenge revisionist accounts by institutional and influential sources.

Emergent discourses still center on facts and evidence of Marcos' historic plunder but entangled in affective intensities (Paasonen, 2015) of anger, disgust, and shock that amplify its resonance in the network. A critical discursive junction is the reappropriation of the hashtag to include present-day figures who are reportedly engaged in graft and corruption, establishing historical continuity of kleptocracy in Philippine politics.

Distinct in the assemblage of counter-memory is the co-option and rejection of the conventions of commemoration through participatory, creative and subversive practices, facilitated by Twitter affordances. The commemoration is framed to 'dishonor' Marcos by naming him as 'murderer', 'monster' and 'Hitler-wanna-be.' It also manifests as personal acts of remembrance through curating, annotating, and transforming historical materials into Twitter vernacular in the form of links, screenshots and threads (Image 1). Artistic expressions define the texture of the commemoration, from engaging in humor and mockery (Image 2) to remixing and editing physical and digital commemorative markers (Image 3 ). 




Figure 1. Counter memory network 


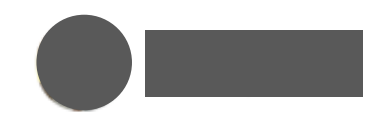

Dahil \#ArawNgMagnanakaw ngayon, ipapakita ko lang sa inyo kung san napunta ang parte ng kaban ng bayan nung panahon ni Marcos.

Their mansion in Tacloban has a grand ballroom with 3 Czechoslovak chandeliers modeled after that in Malacañanang, and a "throne room".

Translate Tweet

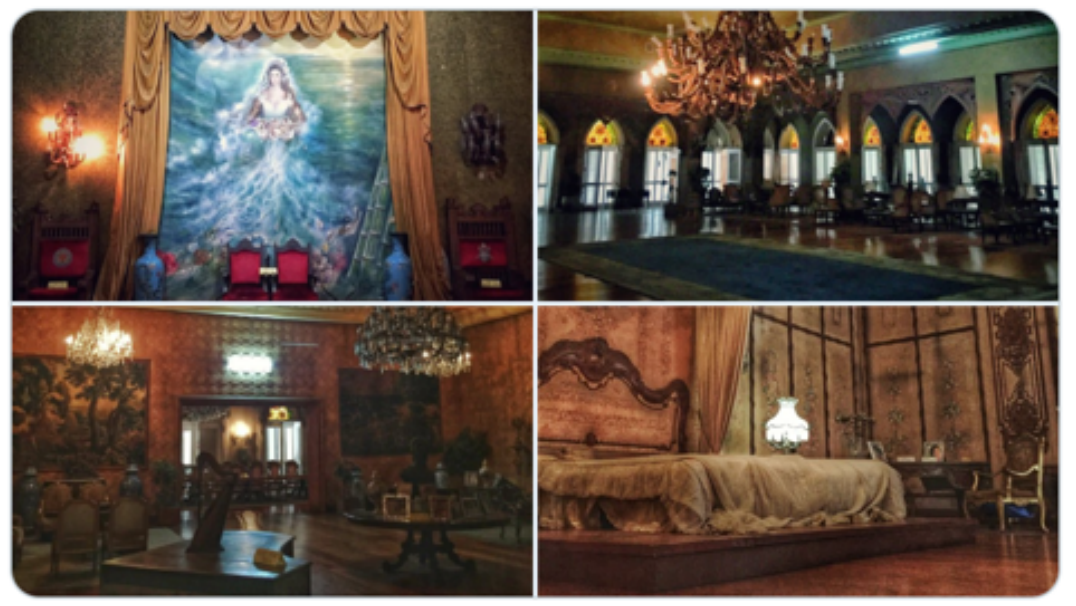

Image 1. Tweet showcasing the lavish mansion of the Marcoses

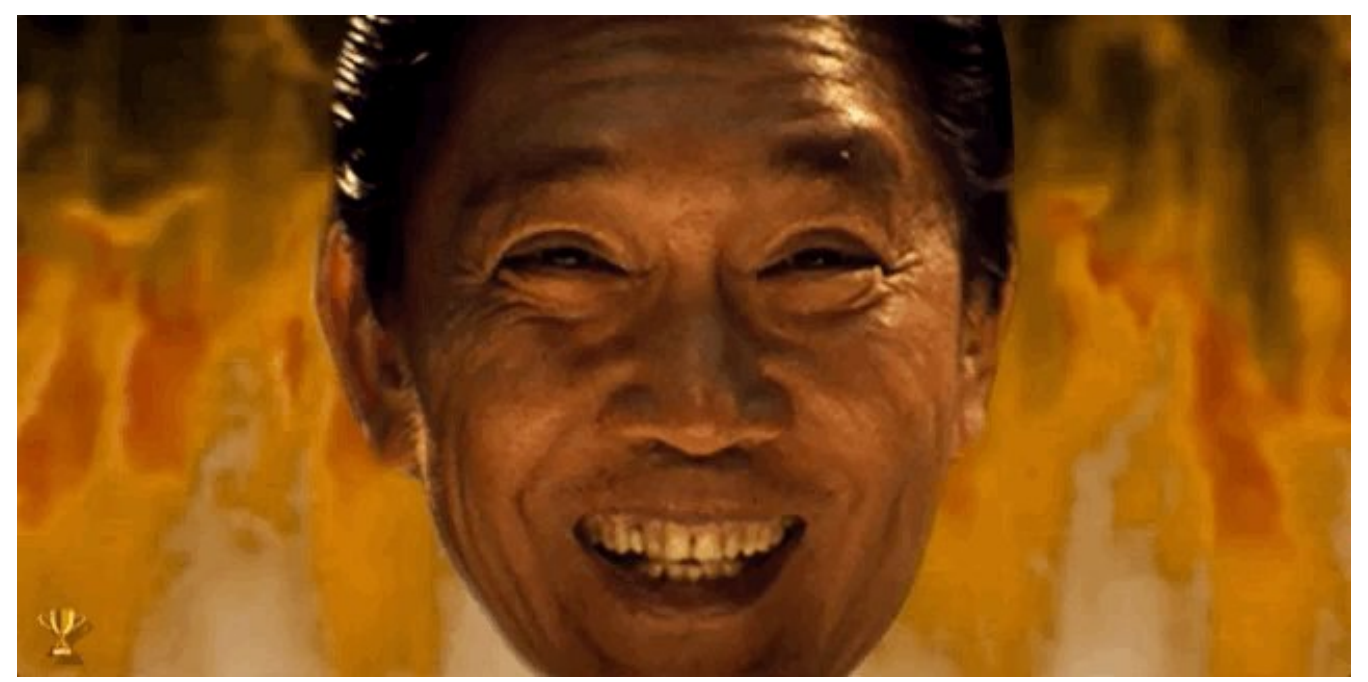

Image 2. GIF of Marcos mimicking the 'Elmo Rise' meme 


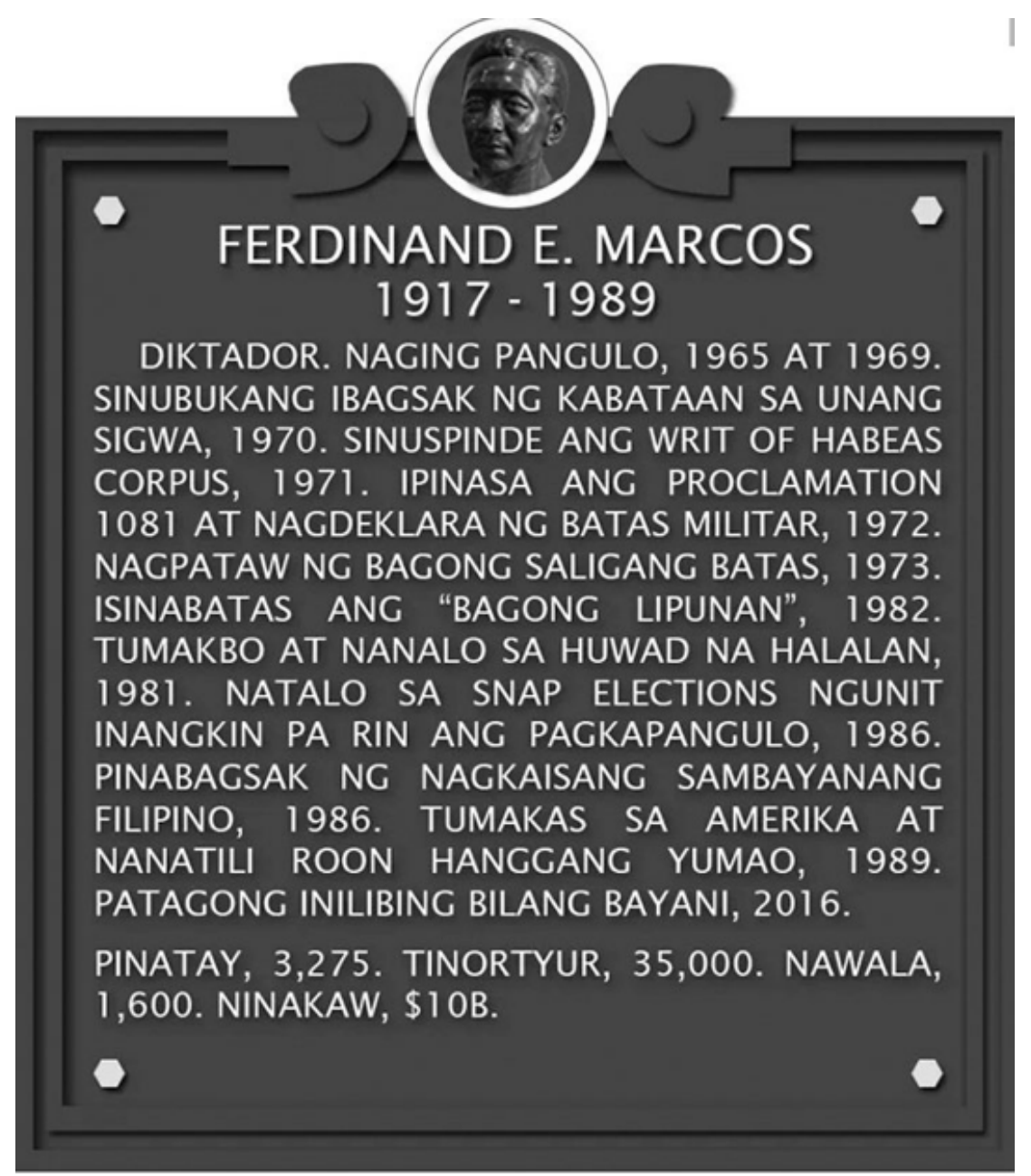

Image 3. A digital plaque detailing Marcos atrocities

\section{Political agency emerging from counter-memory assemblages}

History is often elite-constructed or negotiated through collective movements (Gutman, 2017). The ad hoc unit formed by the counter-memory assemblage wields its power from neither elite nor collective actions, but through connective action (Bennett \& Segerberg 2012). First, the locus of analysis shifts from a single actor ('who remembers') to the assemblage ('what enacts the remembering') as an agent of counter-memory, situating counter-memory as publics, discourses, and technologies that co-constitutes the process of constructing, assembling, and circulating historical accounts. In particular, it acknowledges technology as a structure not only supporting the assemblage, but also shaping its possibilities and boundaries.

Secondly, the assemblage's resistance to elite commemoration surfaces silenced and neglected historical narratives ('what is remembered') through affective articulations of 
protest and subversive commemorative practices ('how is it remembered'). Twitter is culturally ubiquitous but lies outside of established institutions, empowering online publics to determine which narratives are remembered and how they must be remembered. This undermines the privileged position of formal history and allows informal communicative structures like Twitter to participate in memory construction. When the assemblage of counter-memory is mobilized, it is rendered the political agency (Kaun, Kyriakidou \& Uldam, 2016) to resist attempts to revise history for the interests of a few and negotiate for whom history should be written.

Public commemoration mediated by networked technologies of memory manifests as digital assemblages of non-institutional actors, affective discourses, and informal commemorative practices. However, their temporality arrests their potential to institutionalize alternative yet legitimate accounts by unheard or silenced voices. Efforts should be made to document and archive movements and events transpiring in digital media and move their traces to more permanent venues. Outside the digital realm, social institutions also still play a crucial role in the legitimation of memory, and other venues and forms of commemoration where memories are legitimized, (re)constructed, and even revised must be explored, as our study provides only one of long-standing debates about Marcos' legacy in digital media.

\section{References}

Aguilar, F.V.J. (2019). Political conjuncture and scholarly disjunctures: Reflections on studies of the Philippine state under Marcos. Philippine Studies: Historical and Ethnographic Viewpoints 67(1), 3-30.

Armstrong, E. A., \& Crage, S. M. (2006). Movements and memory: The making of the Stonewall myth. American Sociological Review, 71(5), 724-751.

Bennett, W.L. \& Segerberg, A. (2012). The logic of connective action: Digital media and the personalization of contentious politics. Information, communication \& society 15(5), 739-768.

Foucault, M. (1977). Language, counter-memory, practice. New York: Cornell University Press.

Gutman, Y. (2017). Memory Activism: Reimagining the Past for the Future in IsraelPalestine. Nashville: Vanderbilt University Press.

House Bill No. 7137, Republic of the Philippines House of Representative 18th Congress. (2020). https://www.congress.gov.ph/legisdocs/first_18/CR00393.pdf

Jones, R. H., Chik, A., \& Hafner, C. A. (Eds.). (2015). Discourse and digital practices: Doing discourse analysis in the digital age. Routledge.

Kaun, A., Kyriakidou, M., \& Uldam, J. (2016). Political agency at the digital crossroads?. Media and Communication, 4(4), 1-7. 
Liu, J. (2018). Who speaks for the past? Social media, social memory, and the production of historical knowledge in contemporary China. International Journal of Communication, 12, 21.

Paasonen, S. (2015). A Midsummer's Bonfire. In S. Paasonen, K. Hillis, \& M. Petit (Eds.), Networked Affect (pp. 27-42). Cambridge, MA: MIT Press.

Soriano, C.R.R. \& Gaw, F. (2021). Platforms, alternative influence, and networked political brokerage on YouTube. Convergence.

https://doi.org/10.1177/13548565211029769 